\title{
Follow up study of haematological effects in workers exposed to 2-methoxyethanol
}

\author{
T-S Shih, A-T Hsieh, Y-H Chen, G-D Liao, C-Y Chen, J-S Chou, S-H Liou
}

Occup Environ Med 2003;60:130-135

See end of article for authors' affiliations

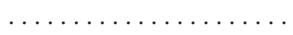

Correspondence to: Dr S-H Liou, School of Public Health, National Defense Medical Center, PO Box 90048-509, Neihu, Taipei, Taiwan 114, Republic of China; shliou@ndmctsgh.edu.tw

Accepted 5 June 2002

\begin{abstract}
Aims: To examine the association between 2-methoxyethanol (2-ME) exposure and haematological effects, as well as the recovery from these haematological effects with continuous reduction in exposure to $2-M E$.

Methods: Twenty nine exposed and 90 non-exposed workers were recruited. Haematological parameters, eight hour full shift personal exposure to 2-ME, and urinary 2-methoxyacetic acid (MAA) were repeatedly measured in three consecutive surveys within six months.

Results: Results of haematological examination in the first exposure survey showed that haemoglobin, packed cell volume, and red blood cell count in the male exposed workers were significantly lower than those in the comparison workers. The frequency of anaemia in the exposed group (42\%) was significantly higher than that in the comparison group (3\%). The haematological effects were significantly associated with the urinary MAA of exposed workers. The haematological effects had returned to normal in the first follow up survey 2.5 months later, when a reduction in 2-ME exposure was noted. Haematological results of the second follow up examination six months later remained normal. The mean airborne exposure of 2-ME in the three surveys dropped from 35.7 to 2.65 , then to $0.55 \mathrm{ppm}$. The mean urinary MAA of exposed workers in the three surveys was reduced from 57.7 to 24.6 , then to $13.5 \mathrm{mg} / \mathrm{g}$ creatinine $(\mathrm{n}=29)$. The reduction in exposure through both inhalation and potential dermal contact with 2-ME might account for the haematological recovery.

Conclusion: 2-ME is a haematological toxin which leads to anaemia in exposed workers. However, the toxic haematological effects of 2-ME persist for only a short period of time after cessation or reduction of exposure.
\end{abstract}

$\mathrm{T}$ he solvent 2-methoxyethanol (2-ME) is widely used in various industries as well as the deicing additives in military jet fuel. ${ }^{12}$ The annual consumption of 2 -ME is over 3000 tons in Taiwan. There are few reports of the exposure to and toxicity of 2-ME occurring in the copper clad laminate manufacturing industry. With the rapid growth of the semiconductor manufacturing industry in Asia, quantitative exposure assessment and toxicity of 2-ME have become increasingly important.

Animal and human studies have shown that 2-ME can cause adverse reproductive, developmental, and haematological effects through inhalation, dermal absorption, and ingestion. $^{2-7}$ 2-ME is metabolised to 2-methoxy aceticacid (MAA) via alcohol dehydrogenase and aldehyde dehydrogenase. ${ }^{8-10}$ In humans, the total amount of MAA excreted in the urine accounts for about $85.5 \%$ of the inhaled 2 -ME. ${ }^{10}$ No background levels of MAA were found in non-exposed people. In vitro studies have shown that 2-ME itself evokes no toxic responses, either in Sertoli cell culture ${ }^{9}$ or in rat whole embryo culture, whereas MAA does. ${ }^{11}$ In vivo studies have shown that equivalent doses of 2-ME and MAA are equally effective in causing adverse effects. ${ }^{912}{ }^{13}$ Experimental human studies have shown that skin absorption might be the major exposure route of 2 -ME. ${ }^{14}{ }^{15}$ Traditional airborne exposure monitoring had difficulties in evaluating the uptake of 2-ME through skin absorption. Urinary MAA, therefore, was suggested as a proximate toxicant and as a specific and suitable biomarker of 2-ME exposures by all routes. ${ }^{18} 11$ 16-19

Some cases of acute or subacute poisoning have been described in human subjects as a result of accidental ingestion or high environmental exposures. ${ }^{20-29}$ The very limited epidemiological studies ${ }^{70}$ suggest that exposure of "mixed" ethylene glycol ethers might account for the haematological effects. However, the association was difficult to clarify because of the complicated mixtures of exposed chemicals (mixed glycol ethers and other haematological toxicants) and very limited human exposure data. Although MAA was suggested to be a good indicator to reflect the integrated exposures of 2-ME, urinary MAA has only been investigated in experimental human exposure studies..$^{101530}$ Direct evidence linking the adverse haematological effects and chronic exposure to 2-ME, particularly the toxic metabolite MAA, is lacking.

Our previous study ${ }^{31}$ showed there to be haematological toxicity ( specifically erythropoietic), but no reproductive toxic effects, among workers exposed to 2-ME at two copper clad laminate manufacturing factories. One of these factories agreed to intervention by control measures. The objectives of this study were to follow up the 2-ME exposure (both airborne exposure of 2-ME and urinary MAA) and the haematological effects, and to examine the reduction in haematological effects through the continuous improvement in working conditions.

\section{MATERIALS AND METHODS \\ Study population}

Twenty nine impregnation workers (24 males and five females) from the coating department of a copper clad laminate manufacturing plant were recruited as the study population. A group of 90 workers, including 32 heat press workers whose working place was adjacent to the coating department and 58 workers from the administrative department working in a separate building, were selected as the

Abbreviations: 2-ME, 2-methoxyethanol; GC/MS, gas chromatography/mass spectrometry; MAA, 2-methoxyacetic acid 
comparison group. All participants were informed and signed consent forms. All were asked not to consume alcohol or medication, and were asked to avoid exposure to other organic solvents during the study period.

\section{Manufacturing processes}

Regular operations in the copper clad laminate manufacturing process include mixing, implantation, drying, cutting, lamination, trimming, and inspection. The main raw materials used in these plants include epoxy and phenolic resins, hardener (dicyanamide), catalyst (2-methylimidazole), antimony oxide, aluminium oxide, silica dioxide, titanium oxide, pigments, acetone, and 2-ME. 2-ME and acetone are the only two volatile chemicals used in this workplace. The solvent of the coating glue contains $70 \% 2-\mathrm{ME}$ and $30 \%$ acetone. The qualitative confirmation of 2-ME in both raw materials and randomly selected air samples was reconfirmed by gas chromatography/ mass spectrometry (GC/MS).

\section{Data collection}

Questionnaires were used to collect information on personal characteristics, personal habits (for example, alcohol consumption and smoking), reproductive history, detailed occupational history, and related symptoms.

\section{Environmental monitoring}

The first exposure survey was held in February 1997, and a personal weekly mean of five day, eight hour full shift mean concentration was used to evaluate the mean airborne exposure of 2-ME for the 29 exposed workers. In the first and second follow up exposure surveys held in April and August, the eight hour full shift personal samples were collected for one day. For the comparison group workers, eight hour full shift personal samples were randomly selected for nine of the 32 workers in the heat press operation, and eight hour full shift fixed point air samples were evenly collected in 10 locations of the administrative department for one day in the first exposure survey.

Airborne 2-ME exposures were measured by Institute of Occupational Safety and Health (IOSH) 1215 recommended sampling and analytical method, ${ }^{32}$ originating from the US NIOSH 1403 and the OSHA 79 method. Active samples are collected by drawing air through standard size $(100 \mathrm{mg} / 50$ $\mathrm{mg}$ ) coconut shell charcoal tubes. Predrying tubes were connected to some of the charcoal tubes to remove water vapour. The materials collected were desorbed in $1 \mathrm{ml}$ of a mixed solvent of 95/5 (v/v) dichloromethane and methanol. The desorbed 2-ME was analysed by gas chromatography with flame ionisation detection. This method was fully validated by the Institute of Occupational Safety and Health (IOSH), Taipei, Taiwan and also by two reference laboratories before it was adopted in this study. GC/MS analysis of bulk samples and randomly selected air samples confirmed that 2-ME and acetone were the only two volatile chemicals in the workplace.

\section{Biological monitoring}

Spot urine samples were collected from both exposed and comparison group workers after they had finished their shift (post-shift) on Friday in three exposure surveys for comparison. Urinary MAA was determined by a previously reported method..$^{33}$ This method was fully validated by IOSH and also by two reference laboratories before it was adopted in this study. Urinary creatinine was analysed by the Jaffe method for concentration correction.

\section{Medical examination}

About $10 \mathrm{ml}$ of blood was collected for all participants in the medical department of the factory by an occupational physician in the next workweek after air samples were collected in the three surveys. Haematological parameters, including haemoglobin, packed cell volume, white blood cells, red blood cells, neutrophils, lymphocytes, platelets, mean corpuscular volume, mean corpuscular haemoglobin, were examined in each survey. In addition, liver and renal function, routine urine tests, and neurological symptoms were checked during each physical examination. All blood samples collected in the three surveys were examined by the same hospital; 44 randomly selected blood samples were analysed for haemoglobin by a second hospital as a check of quality control.

\section{Statistical analysis}

Student's $t$ test and $\chi^{2}$ test were used to compare differences of haematological parameters between the exposed and comparison groups. Analysis of variance for repeated measurements was used to compare differences in haematological outcomes among the three surveys. Multiple linear regression was used to examine the dose-response relation between airborne 2-ME concentrations or urinary MAA concentrations and haematological outcome.

\section{RESULTS}

\section{Distribution of characteristics among study subjects}

No significant differences in the distribution of characteristics (age, duration of employment, body mass index, sex, martial status, or smoking status) were found between 29 exposed and 90 comparison workers (table 1). Most workers were males; about half were smokers. Mean duration of employment was about three years.

\section{Environmental and biological monitoring data}

For the first exposure survey, the personal five day weekly mean concentration of airborne 2-ME in the exposed group was 35.7 ppm (SD 77.9, range 0.75-320 ppm, $\mathrm{n}=29$ ) (table 2 ). Much higher peak daily exposure was detected for glue preparation and machine cleaning operations. The exposure to 2-ME for heat press workers in the comparison group was 0.19 ppm ( SD 0.30, range ND-0.80 ppm, $\mathrm{n}=9$ ). The eight hour full shift mean fixed point air samples showed that no 2-ME was detected in the administrative department.

The mean post-shift urinary MAA concentration on Friday of exposed workers was $57.7 \mathrm{mg} / \mathrm{g}$ creatinine (SD 31.8, range $24.3-139 \mathrm{mg} / \mathrm{g}$ creatinine, $\mathrm{n}=29$ ) A low concentration of MAA was found in some heat press workers whose working position was closely adjacent to the coating department. The mean MAA concentration of 32 workers in the heat press

Table 1 Distribution of characteristics among the study population

\begin{tabular}{llll}
\hline Variable & Exposed $(\mathrm{n}=29)$ & Comparison $(\mathrm{n}=90)$ & $\mathrm{p}$ value \\
\hline Age $(\mathrm{y}$, mean $(\mathrm{SD}))$ & $29.24(6.61)$ & $29.23(6.82)$ & 0.99 \\
Duration of employment (y, mean (SD)) & $2.89(2.20)$ & $3.59(2.83)$ & 0.23 \\
Body mass index $\left(\mathrm{kg} / \mathrm{m}^{2}\right.$, mean (SD)) & $22.43(3.19)$ & $22.30(3.44)$ & 0.86 \\
Sex (male, $\mathrm{n}(\%))$ & $24(82.8)$ & $67(74.4)$ & 0.36 \\
Marital status (single, $\mathrm{n}(\%))$ & $12(41.4)$ & $44(48.9)$ & 0.48 \\
Smoking status (smoker, $\mathrm{n}(\%))$ & $16(55.2)$ & $49(54.4)$ & 0.95 \\
\hline
\end{tabular}


Table 2 2-ME air concentrations and Friday post-shift urinary MAA concentrations among exposed and comparison group workers in baseline and two follow up surveys

\begin{tabular}{|c|c|c|c|c|}
\hline & \multicolumn{3}{|l|}{ Exposed group } & \multirow{2}{*}{$\begin{array}{l}\text { Comparison group* } \\
\text { February }\end{array}$} \\
\hline & February & April & August & \\
\hline \multicolumn{2}{|l|}{ Air 2-ME } & \multicolumn{2}{|l|}{$(n=29)$} & $(n=9 \dagger)$ \\
\hline Mean (SD) (ppm) & $35.7(77.9) \ddagger$ & $2.65(1.53) \S$ & $0.55(0.73) \S$ & $0.19(0.30) \S$ \\
\hline GM (GSD) (ppm) & $9.62(4.75)$ & $2.34(1.76)$ & 0.34 (2.69) & 0.08 (5.09) \\
\hline Minimum (ppm) & 0.75 & 0.2 & 0.1 & ND \\
\hline Maximum (ppm) & 320 & 10 & 3.5 & 0.80 \\
\hline \multicolumn{2}{|l|}{ Urinary MAA } & \multicolumn{2}{|l|}{$(n=29)$} & $(n=32)$ \\
\hline Mean (SD) (mg MAA/g Cr) & $57.7(31.8) \uparrow$ & 24.6 (14.7) & $13.5(10.6) \pi$ & $1.02(1.25) \mathbb{1}$ \\
\hline GM (GSD) (mg MAA/g Cr) & $50.7(1.67)$ & 19.7 (2.09) & 6.77 (4.19) & $0.53(3.40)$ \\
\hline Minimum (mg MAA $/ \mathrm{g} \mathrm{Cr}$ ) & 24.3 & 4.60 & 0.95 & $N D * *$ \\
\hline Maximum (mg MAA/g Cr) & 139 & 54.9 & 25.2 & 4.22 \\
\hline \multicolumn{5}{|c|}{$\begin{array}{l}\text { *2-ME was not detected in } 10 \text { locations of the administrative department of the comparison group. } \\
\text { tNine of the } 32 \text { workers in the heat press operation were randomly selected for personal monitoring. } \\
\text { †Five day weekly personal mean exposure concentrations. } \\
\text { §Daily personal eight hour full shift mean concentrations. } \\
\text { TMAA concentration of Friday post-shift urine samples. } \\
\text { **MAA was not detected in urine samples of workers in the administrative department of the comparison } \\
\text { group. } \\
\text { GM, geometric mean; GSD, geometric standard deviation; ND, non-detectable; } C r \text {, creatinine. }\end{array}$} \\
\hline
\end{tabular}

operation was $1.02 \mathrm{mg} / \mathrm{g}$ creatinine (SD 1.25, range ND-4.22 $\mathrm{mg} / \mathrm{g}$ creatinine, $\mathrm{n}=32$ ). No MAA was detected in the comparison workers from the administrative department.

For the first follow up exposure survey, the personal eight hour full shift mean concentration of airborne 2-ME of the study group was $2.65 \mathrm{ppm}$ (SD 1.53, range $0.2-10 \mathrm{ppm}$, $\mathrm{n}=29$ ). The mean post-shift urinary MAA concentration on Friday of exposed workers was $24.6 \mathrm{mg} / \mathrm{g}$ creatinine (SD 14.7, range $4.6-54.9 \mathrm{mg} / \mathrm{g}$ creatinine, $\mathrm{n}=29$ ) (table 2 ).

For the second follow up exposure survey, the personal eight hour full shift mean concentration of airborne 2-ME of the study group was $0.55 \mathrm{ppm}$ (SD 0.73, range 0.1-3.5 ppm, $\mathrm{n}=29$ ) The mean post-shift urinary MAA concentration on Friday of exposed workers was $13.5 \mathrm{mg} / \mathrm{g}$ creatinine (SD 10.6, range $0.95-25.2 \mathrm{mg} / \mathrm{g}$ creatinine, $\mathrm{n}=29$ ) (table 2 ).

Table 2 presents a summary of results of both airborne 2-ME and urinary MAA concentrations obtained from the baseline and two follow up surveys; a decreasing trend is seen. A combination of engineering controls and improvement in working practices accounts for the reduction in 2-ME exposure.

\section{Baseline haematological outcome and its relation to 2-ME exposure}

High correlation was found between the results of haemoglobin values of randomly selected split samples analysed by two hospitals $(r=0.951, \mathrm{p}<0.001, \mathrm{n}=44)$. Table 3 shows results of haematological examination and exposure assessment stratified by gender for the first exposure survey. Haemoglobin, packed cell volume, and red blood cell count were significantly lower in male exposed workers than in male comparison group workers. However, there were no significant differences in haemoglobin, packed cell volume, and red blood cell count among female workers. The exposure levels of 2-ME and urinary MAA in the male exposed workers were significantly higher than those in both female exposed workers and comparison group workers $(p<0.001)$.

If the cut off points for abnormal values in males for haemoglobin of $135 \mathrm{~g} / \mathrm{l}$, packed cell volume of $40 \%$, red blood cell count of $4.5 \times 10^{12} / \mathrm{l}$, white blood cell count of $5 \times 10^{9} / \mathrm{l}$, and platelets of $150 \times 10^{9} / 1$ were used, the mean proportion of abnormal values in the baseline survey for haemoglobin, packed cell volume, and red blood cell count in the exposed

Table 3 Comparison of mean baseline haematological parameters and exposure levels among the exposed and comparison group workers stratified by gender

\begin{tabular}{|c|c|c|c|c|c|c|}
\hline \multirow[b]{2}{*}{ Parameter } & \multicolumn{3}{|l|}{ Male } & \multicolumn{3}{|l|}{ Female } \\
\hline & $\begin{array}{l}\text { Exposed group } \\
(n=24)\end{array}$ & $\begin{array}{l}\text { Comparison } \\
\text { group }(n=67)\end{array}$ & p value* & $\begin{array}{l}\text { Exposed group } \\
(n=5)\end{array}$ & $\begin{array}{l}\text { Comparison } \\
\text { group }(n=23)\end{array}$ & p value* \\
\hline Haemoglobin (g/l) & $137(185)$ & 155 (110) & $<0.001$ & $129 \quad(261)$ & 124 (114) & 0.483 \\
\hline Packed cell volume (\%) & $41.8(5.60)$ & $48.1(3.22)$ & $<0.001$ & $39.4(7.16)$ & 40.2 (3.01) & 0.694 \\
\hline $\operatorname{RBC} \dagger\left(10^{12} / \mathrm{I}\right)$ & $4.54(0.72)$ & $5.47(0.56)$ & $<0.001$ & $4.18(0.77)$ & $4.72(0.57)$ & 0.085 \\
\hline WBC† $\left(10^{9} / I\right)$ & $7.48(2.36)$ & 7.08 (1.77) & 0.383 & $7.90(5.03)$ & $6.40(1.56)$ & 0.222 \\
\hline Neutrophils $\left(10^{\circ} / \mathrm{I}\right)$ & 4.38 (1.93) & $4.51(1.41)$ & 0.721 & $5.60(4.26)$ & $4.05(1.26)$ & 0.135 \\
\hline Lymphocytes $\left(10^{\circ} / I\right)$ & $2.76(0.77)$ & $2.17(0.47)$ & $<0.001$ & $1.95(0.75)$ & $1.98(0.47)$ & 0.907 \\
\hline Platelets $\left(10^{\circ} /\right.$ I) & $305(60.6)$ & $248(59.1)$ & $<0.001$ & $258 \quad(65.9)$ & 254 & 0.920 \\
\hline $\mathrm{MCV} \dagger(\mathrm{fl})$ & $92.6(6.79)$ & $88.6(7.79)$ & 0.030 & 94.5 (4.61) & $86.2(10.4)$ & 0.096 \\
\hline $\mathrm{MCH} \dagger(\mathrm{pg})$ & $30.5(2.27)$ & $28.6(2.95)$ & 0.007 & $30.9(2.21)$ & $26.6(3.71)$ & 0.020 \\
\hline $\mathrm{MCHC} †(g / \mu l)$ & $32.9(0.81)$ & $32.2(1.08)$ & 0.009 & $32.7(1.13)$ & $30.8(1.24)$ & 0.005 \\
\hline 2-ME, mean $(S D)(p p m)$ & $41.9(83.5)$ & $0.19(0.30) \ddagger$ & $<0.001$ & $5.94(3.59)$ & - & - \\
\hline $\mathrm{MAA}$, mean $(\mathrm{SD})$ (mg/g creatinine) & $66.2(46.9)$ & $1.02(1.25) \S$ & $<0.001$ & $16.8(9.40)$ & - & - \\
\hline
\end{tabular}

*Student's $t$ test.

†Abbreviations: RBC, red blood cells; WBC, white blood cells; MCV, mean corpuscular volume; $M C H$, mean corpuscular haemoglobin; $M C H C$, mean corpuscular haemoglobin concentration.

$\ddagger 2-M E$ exposure data of 9 of the 32 workers in the heat press operation. 2-ME was not detected in the administrative department.

$\S$ Urinary MAA concentration of 32 male workers in the heat press operation. MAA was not detected in the administrative department. 


\begin{tabular}{|c|c|c|c|c|}
\hline Dependent variable & Independent variable & $\begin{array}{l}\text { Regression } \\
\text { coefficient }\end{array}$ & SD & $p$ value \\
\hline \multirow[t]{5}{*}{ Haemoglobin } & Constant & 14.95 & 1.95 & \\
\hline & Sex & -2.22 & 0.52 & $<0.001$ * \\
\hline & $\mathrm{BMl}$ & 0.12 & 0.09 & 0.173 \\
\hline & Work-year & -0.02 & 0.11 & 0.866 \\
\hline & $\log (\mathrm{MAA} / \mathrm{Cr})$ & -1.07 & 0.36 & $0.005^{*}$ \\
\hline \multirow[t]{5}{*}{ Packed cell volume } & Constant & 45.19 & 5.52 & \\
\hline & Sex & -5.60 & 1.47 & $<0.001^{*}$ \\
\hline & BMI & 0.37 & 0.24 & 0.130 \\
\hline & Work-year & -0.08 & 0.32 & 0.813 \\
\hline & $\log (\mathrm{MAA} / \mathrm{Cr})$ & -4.23 & 1.03 & $<0.001$ * \\
\hline \multirow[t]{5}{*}{ Red blood cells } & Constant & 5.40 & 0.70 & \\
\hline & Sex & -0.43 & 0.19 & 0.025 \\
\hline & BMI & 0.01 & 0.03 & 0.717 \\
\hline & Work-year & 0.05 & 0.04 & 0.273 \\
\hline & $\log (\mathrm{MAA} / \mathrm{Cr})$ & -0.63 & 0.13 & $<0.001$ * \\
\hline \multirow[t]{5}{*}{ White blood cells } & Constant & 2.08 & 2.48 & \\
\hline & Sex & 0.27 & 0.66 & 0.682 \\
\hline & BMI & 0.24 & 0.11 & 0.030 \\
\hline & Work-year & -0.28 & 0.14 & 0.051 \\
\hline & $\log (\mathrm{MAA} / \mathrm{Cr})$ & 0.12 & 0.46 & 0.803 \\
\hline \multirow[t]{5}{*}{ Platelets } & Constant & 146.43 & 76.83 & \\
\hline & Sex & 18.40 & 20.39 & 0.372 \\
\hline & BMI & 4.36 & 3.35 & 0.199 \\
\hline & Work-year & -3.54 & 4.40 & 0.425 \\
\hline & $\log (\mathrm{MAA} / \mathrm{Cr})$ & 22.34 & 14.32 & 0.126 \\
\hline
\end{tabular}

male workers (42\%) would be significantly higher than those of the comparison control male workers $(3 \%)(p<0.001)$.

The multiple regression model in the baseline survey showed that red blood cell count was significantly and negatively associated with airborne 2-ME concentration. Table 4 shows that haemoglobin, packed cell volume, and red blood cell count were significantly and negatively associated with urinary MAA. However, white blood cell and platelet counts were not associated with either airborne 2-ME or urinary MAA concentrations.

\section{Haematological changes in six months}

Table 5 shows changes in haematological parameters for male 2-ME-exposed workers in the three surveys. Haemoglobin, packed cell volume, and red blood cell count were found to have returned to normal values in both the first $(2.5$ months later) and the second (six months later) follow up exposure surveys. In addition, a significant increasing trend was noted for haemoglobin, packed cell volume, and red blood cell count.
Although the platelet count was still within the normal limits, a significant decreasing trend was also noted. No significant trend was found for white blood cells, lymphocytes, or neutrophil counts. No significant trend was found among the three surveys for female exposed workers.

\section{DISCUSSION}

To the best of our knowledge, this is the only study that longitudinally examines changes in haematological effects and documents a continuous reduction in exposure to 2-ME with reliable exposure data on both airborne exposure and workers' urinary MAA. The few previous epidemiological studies ${ }^{70}$ examined the health effects using very limited cross sectional exposure data without excluding the co-exposure of other complicating haematological toxicants. This study provides strong supporting evidence for the toxicity of 2-ME as well as additional information on what "low" exposure is and how quickly these health effects decrease or are avoided if improvements are carried out.

Table 5 Haematological changes in baseline and two follow up studies among 24 male workers exposed to 2-ME

\begin{tabular}{|c|c|c|c|c|}
\hline Parameter & February & April & August & $p$ value \\
\hline Haemoglobin (g/l) & 137 (185) & 152 (075) & 155 (088) & $<0.001$ * \\
\hline Packed cell volume (\%) & $41.8(5.60)$ & $45.2(2.20)$ & $48.2(2.43)$ & $<0.001^{*}$ \\
\hline $\operatorname{RBC}\left(10^{12} / \mathrm{I}\right)$ & $4.54(0.72)$ & $4.93(0.40)$ & $5.26(0.36)$ & $<0.001$ * \\
\hline $\operatorname{WBC}\left(10^{\circ} / \mathrm{I}\right)$ & $7.48(2.36)$ & $6.84(1.48)$ & $7.12(1.29)$ & 0.095 \\
\hline Neutrophils $\left(10^{9} / 1\right)$ & 4.38 (1.93) & $4.28(1.38)$ & 4.34 (1.39) & 0.244 \\
\hline Lymphocytes $\left(10^{\circ} / \mathrm{l}\right)$ & $2.76(0.77)$ & $2.32(0.75)$ & $2.25(0.63)$ & 0.137 \\
\hline Platelets $\left(10^{\circ} / \mathrm{l}\right)$ & $305(60.6)$ & $254(57.2)$ & $237(64.8)$ & $<0.001$ * \\
\hline MCV (fl) & $92.6(6.79)$ & $92.0(6.10)$ & $91.8(6.23)$ & 0.058 \\
\hline $\mathrm{MCH}(\mathrm{pg})$ & $30.5(2.27)$ & $30.9(2.28)$ & $29.5(2.20)$ & $<0.001$ * \\
\hline $\mathrm{MCHC}(\mathrm{g} / \mu \mathrm{l})$ & $32.9(0.81)$ & $33.5(0.78)$ & $32.1(0.80)$ & $<0.001^{*}$ \\
\hline
\end{tabular}

†MANOVA for repeated measurement; * $p<0.05$

See table 3 for abbreviations. 
After the first exposure survey, the authors recommended that this copper clad laminate manufacturing enterprise should carry out some critical interventions under our supervision. All coating machinery was installed in the enclosed rooms with aluminium sliding doors. Incinerators were installed above each coating machine to burn off the waste solvent exhaust vapours. New local ventilation was installed in areas of raw material mixing, charging, and discharging. Workers were asked to wear respirators and rubber gloves (cotton gloves were stringently prohibited) when they entered the coating rooms for maintenance, troubleshooting, or for machine cleaning. They were also asked to stay in the coating rooms for as short a time as possible and to close the door immediately when they left. All spills of glues and solvents were cleaned up immediately. With the close collaboration of the employer, managers, employees, engineers, occupational safety and health professionals in this factory, and IOSH researchers, workers' 2-ME exposures and their urinary MAA concentrations were significantly reduced in a very short period of time.

Several studies have shown that skin absorption is a major exposure route for 2-ME..$^{14}{ }^{15}{ }^{34}$ Urinary MAA, therefore, was recommended as a specific and suitable indicator for occupational exposure to 2 -ME by all routes and may reflect the concentration of the "active agent" at the target sites. ${ }^{1}$ In this study, urinary MAA showed a significant negative doseresponse relation with haematological parameters. In the follow up surveys, workers' haematological parameters and urinary MAA rapidly decreased after their airborne exposures were reduced. This shows that the haematological effects might be caused by a combination of moderately high inhalation exposure and repeated skin exposure to 2-ME. Urinary MAA might be a specific and suitable biomarker of integrated exposure to 2-ME.

All raw materials, operating conditions, manufacturing facilities, productivity, and working hours remained quite similar during the entire year. GC/MS analysis confirmed that $2-\mathrm{ME}$ and acetone were the only two volatile raw materials. No haematological toxicants other than MAA were used in this workplace. 2-ME is not used in commercial products in Taiwan. ${ }^{34}$ No background urinary MAA was detected in the non-exposed administrative department workers. This is consistent with results of previous reports. ${ }^{17}$

Haematological disorders including leukopenia, lymphocytosis, pancytopenia, marrow depression, and decreased red blood cell count, haemoglobin, and platelet count have been reported as the most common health effects of 2-ME. ${ }^{24} 252735$ Similar haematological disorders, including decreased concentrations of haemoglobin and packed cell volume, decreased white and red blood cell counts, reduced bone marrow cellularity, and reduced erythropoiesis and haemolysis have also been confirmed in animal studies with 2-ME exposure. ${ }^{1}$ In addition to case reports and animal studies, haematological effects of 2-ME intoxication were also found in several epidemiological investigations. ${ }^{72} 30$ Our study also depicts a higher proportion of anaemia and lower mean haemoglobin, packed cell volume, and red blood cell counts in the male exposed group in comparison with the male comparison group. However, the white blood cell and platelet counts were not reduced in the exposed group. These findings are consistent with previous studies showing that high exposure to 2-ME will induce haematological defects. There were no significant differences in haemoglobin, packed cell volume, and red blood cell count among female workers. Female workers stayed mainly in the location of product compiling, which was far from the emission source with much lower exposures. Furthermore, the sample size of female exposed workers was very small $(n=5)$. These observations could explain why there were no statistical differences in the female haematological parameters.

Both animal studies and case reports have shown that the haematological changes can return to normal several weeks to several months after eliminating or reducing exposure. ${ }^{18252829}$ Cohen reported a 2-ME intoxication case showing that the haematological effects were reduced to normal one month after eliminating the exposure. ${ }^{25}$ Larese et al also reported that three 2-ME induced haematological effects returned to normal on eliminating the exposure. ${ }^{35}$ Our follow up observations confirm the reversibility of 2-ME induced haematological effects.

This study illustrates the value of periodical health examinations where there are appropriate medical tests available to assess the effects of an occupational toxin. Haematological effects have been reported with 2-ME toxicity. The study suggests that complete blood count parameters, particularly depression of haemoglobin, packed cell volume, and red blood cell count, might be good indicators for adverse effects of 2-ME.

In conclusion, 2-ME can induce reversible toxic effects, and the hematopoietic system seems to be the main target of chronic exposure. However, the toxic haematological effects of 2-ME persist for only a short period of time after eliminating or reducing exposures. Since skin absorption (either liquid contact or whole body vapour absorption) is difficult to avoid completely, it is not sufficient to only monitor exposure through inhalation. Urinary MAA is a suitable and specific biomarker of integrated exposure to 2-ME.

\section{ACKNOWLEDGEMENTS}

This work was supported by a grant (IOSH-90-A307) from the Institute of Occupational Safety and Health, Council of Labor Affairs, Executive Yuan, Taiwan, Republic of China.

\section{Authors' affiliations}

T-S Shih, C-Y Chen, J-S Chou, Institute of Occupational Safety and Health, Council of Labor Affairs, Taipei, Taiwan, Republic of China A-T Hsieh, Y-H Chen, Tri-Service General Hospital, National Defense Medical Center, Taipei

G-D Liao, S-H Liou, School of Public Health, National Defense Medical Center

\section{REFERENCES}

1 National Institute of Occupational Safety and Health. Criteria for a recommended standard-occupational exposure to ethylene glycol monomethyl ether, ethylene glycol monoethyl ether, and their acetates. Washington, DC: NIOSH, 1991 (Publication number 91-119).

2 Occupational Safety and Health Administration. Occupational exposure to 2-methoxy ethanol, 2-ethoxy ethanol, and their acetates (glycol ethers); proposed rule. Federal Register. Washington, DC: 29CFR, Vol. 58, No. 54, Docket No. H-044, OSHA, 1993.

3 Nagano K, Nakayama E, Oobayashi H, et al. Experimental studies on toxicity of ethylene glycol monomethyl ether in Japan. Environ Health Perspect 1984;57:75-84

4 Larese F, Fiorito A, Zotti RD. The possible haematological effects of glycol monomethyl ether in a frame factory. $\mathrm{Br} J$ Ind Med 1992:49:131-3.

5 Wickramaratne GA. The teratogenic potential and dose-response of dermally administered ethylene glycol monomethyl ether estimated in rats with the Chernoff-Kavlock assay. J Appl Toxicol 1986;6: 165-6.

6 Welch LS, Schrader SM, Turner TW, et al. Effects of exposure to ethylene glycol ethers on shipyard painters: II. Male reproduction. Am J Ind Med 1988;14:509-26.

7 Welch LS, Cullen MR. Effects of exposure to ethylene glycol ethers on shipyard painters: III. Hematological effects. Am J Ind Med 1988; 14:527-36.

8 Miller RR, Hermann EA, Langvardt PW, et al. Comparative metabolism and disposition of ethylene glycol monomethyl ether and propylene glycol monomethyl ether in male rats. Toxicol Appl Pharmacol 1983:67:229-37

9 Moss EJ, Thomas LV, Cook MW, et al. The role of metabolism in 2-methoxy ethanol induced testicular toxicity. Toxicol Appl Pharmacol 1985;79:480-9

10 Groeseneken D, Veulemas H, Masschelein R, et al. Experimental human exposure to ethylene glycol monomethyl ether. Int Arch Occp Environ Health 1989:61:243-7.

11 Yonemoto J, Brown NA, Webb M. Effects of dimethoxyl phthalate, monomethoxyethyl phthalate, 2-methoxyethanol and methoxyacetic acid on post-implanatation rat embryos in culture. Toxicol Lett 1984;21:97-102.

12 Miller RR, Carreon RE, Young JT, et al. Toxicity of methoxyacetic acid in rats. Fund Appl Toxicol 1982;2:158-60. 
13 Sleet RB, Greene JA, Welsch F. The relationship of embryotoxicity to disposition of 2-methoxyethanol in mice. Toxicol Appl Pharmacol 1988;93: 195-207.

14 Shih TS, Wang PY, Chen CY, et al. Measurement of percutaneous uptake of 2-methoxy ethanol vapor in humans. J Occup Environ Med 2000;42:475-82.

15 Kezic S, Mahieu K, Monster A, et al. Dermal absorption of vaporous and liquid 2-methoxyethanol and 2-ethoxyethanol in volunteers. Occup Environ Med 1997;54:38-43.

16 Shih TS, Liou $\mathrm{SH}$, Chen $\mathrm{CY}$, et al. Correlation between urinary 2-methoxy acetic acid and exposure of 2-methoxy ethanol. Occup Environ Med 1999;56:674-8.

17 American Conference of Governmental Industrial Hygienists. TLVs threshold limit values for chemical substances and physical agents and biological indices (BEIs). Cincinnati, OH: ACGIH, 1998:97-101.

18 Brown NA, Holt D, Webb $M$. The teratogenicity of methoxyacetic acid in the rat. Toxicol Lett 1984;22:93-100.

19 Ritter EJ, Scott WJ Jr, Randall JL, et al. Teratogenicity of dimethoxyethyl phthalate and its metabolites methoxy ethanol and methoxyacetic acid in the rat. Teratology 1985:32:25-31.

20 Werner HW, Mitchell JL, Mitchell JW, et al. The acute toxicity of vapors of several monoalkyl ethers of ethylene glycol. J Ind Hyg Toxicol 1943;25:157-63.

21 Pastenbach DJ. Assessment of the developmental risks resulting from occupational exposure to select glycol ethers within the semiconductor industry. J Ind Hyg Toxicol 1988;23:29-75.

22 Greenburg L, Mayors MR, Goldwater L, et al. Health hazards in the manufacturer of used collars: I. Exposure to ethylene glycol monomethyl ether. J Ind Hyg Toxicol 1938;20:134-47.

23 Young EG, Wooner LB. A case of fatal poisoning from 2-methoxy ethanol. J Ind Hyg Toxicol 1946;28:267-8.
24 Zavon MR. Methyl cellosolve intoxication. Am Ind Hyg Assoc J 1963;24:36-41.

25 Cohen R. Reversible subacute ethylene glycol monomethyl ether toxicity associated with microfilm production: a case report. Am J Ind Med 1984;6:441-6.

26 Donley DE. Toxic encephalopathy and volatile solvents in industry. J Ind Hyg Toxicol 1970;18:277-80.

27 Parsons CE, Parsons ME. Toxic encephalopathy and granulopenic anemia due to volatile solvents in industry: report of two cases. J Ind Hyg Toxicol 1938;20:124-33.

28 Nitter-Hauge S. Poisoning with ethylene glycol monomethyl ether: report of two cases. Acta Med Scand 1970;188:277-80.

29 Ohi G, Wegman DH. Transcutaneous ethylene glycol monomethyl ether poisoning in the work setting. J Occup Med 1978;20:675-6.

30 Cook RR, Bodner KM, Kolesar RC, et al. A cross-sectional study of ethylene glycol monomethyl ether process employees. Arch Environ Health 1982;37:346-5

31 Shih TS, Hsieh AT, Liao GD, et al. Haematological and spermatotoxic effects of ethylene glycol monomethyl ether in copper clad laminate factories. Occup Environ Med 2000;57:348-52.

32 Shih TS, Chen CY, Cheng RI, et al. Field evaluation of a passive sampler for 2-methoxy ethanol exposure assessment. Int Arch Occup Environ Health 2000;73:98-104.

33 Shih TS, Chou JS, Chen CY, et al. Improved method to measure urinary alkoxy acetic acids. Occup Environ Med 1999:56:460-7.

34 Institute of Occupational Safety and Health. Exposure assessment of ethylene glycol ethers in Taiwan. Taipei: IOSH, 1995 (Publication No. IOSH-84-A311).

35 Larese F, Fiorito A, Zotti RD. The possible haematological effects of glycol monomethyl ether in a frame factory. $\mathrm{Br} J$ Ind Med 1992;49:131-3.

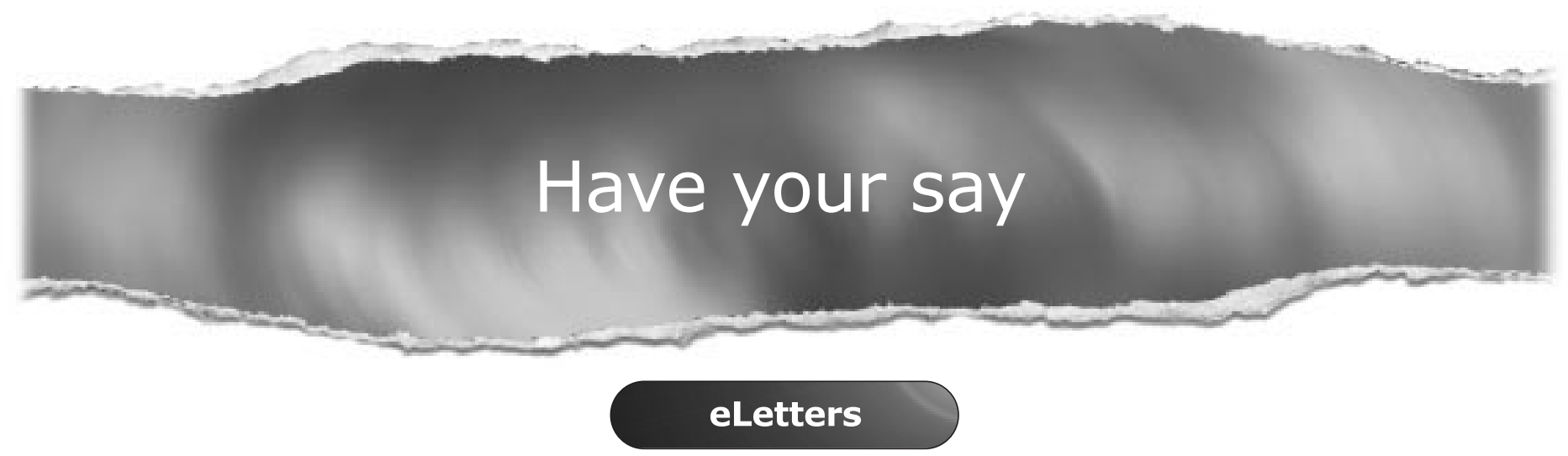

If you wish to comment on any article published in Occupational and Environmental Medicine you can send an eLetter using the eLetters link at the beginning of each article. Your response will be posted on Occupational and Environmental Medicine online within a few days of receipt (subject to editorial screening).

www.occenvmed.com 